\title{
PERAN PEMERINTAH DAERAH \\ DALAM PENYELENGGARAAN KESEHATAN REPRODUKSI (STUDI DI PROVINSI JAWA TENGAH DAN PROVINSI KALIMANTAN BARAT)
}

\author{
The Role of Local Government in the Implementation of Reproductive Health \\ (Study in Central Java Province and West Kalimantan Province)
}

\author{
Sali Susiana \\ Pusat Penelitian Badan Keahlian DPR RI \\ Jl. Gatot Subroto Senayan Jakarta
}

Naskah diterima: 1 April 2016

Naskah dikoreksi: 9 Mei 2016

Naskah diterbitkan: Juni 2016

\begin{abstract}
Abstact: Government Regulation Number 61 Year 2014 on Reproductive Health stated that reproductive health services are not only the responsibility of the central government but also local governments, both at provincial and district/city levels. The problem of this research is on the role of local governments in the implementation of reproductive health. The results using qualitative research methods showed, local government policy related to the implementation of women's reproductive health in two areas being investigated were relatively good. Related to the implementation of Government Regulation No. 61 Year 2014 on Reproductive Health, both provinces have addressed the issues governed by this regulation, especially those related to the implementation of adolescent reproductive health and efforts to reduce Maternal Mortality Rate (MMR). In Central Java Province, high maternal mortality rate has been one focus of RPJMD Year 2013-2018. Efforts are being made to suppress AKI among others, by implementing Active Standby Village Program, Program of House Live Birth, and Shelter for pregnant women. While in West Kalimantan Province, there is Regional Regulation Number 3 Year 2013 on Implementation of Reproductive Health. In Central Java Province, implementation of health services for mothers and children is still hampered by unmet infrastructure and facilities and the prevalence of empowerment and competence of health professional. Similarly in the West Kalimantan Province. Related obstacles are in poor services, as well as high rates of early marriage as two problems encountered in the implementation of reproductive health.
\end{abstract}

Keywords: Reproductive Health, Maternal Mortality Rate, Government Regulation Number 61 Year 2014, Province of Central Java, the West Kalimantan Province.

\begin{abstract}
Abstrak: Peraturan Pemerintah Nomor 61 Tahun 2014 tentang Kesehatan Reproduksi menyatakan pelayanan kesehatan reproduksi tidak hanya menjadi tanggung jawab pemerintah, melainkan juga pemerintah daerah, baik pemerintah provinsi maupun kabupaten/kota. Permasalahan penelitian ini adalah bagaimana peran pemerintah daerah dalam penyelenggaraan kesehatan reproduksi. Hasil penelitian dengan menggunakan metode penelitian kualitatif menunjukkan, kebijakan pemerintah daerah terkait dengan penyelenggaraan kesehatan reproduksi perempuan di dua daerah yang diteliti cukup baik. Terkait dengan implementasi Peraturan Pemerintah Nomor 61 Tahun 2014 tentang Kesehatan Reproduksi di daerah, kedua provinsi telah melaksanakan beberapa hal yang diatur dalam PP tersebut, terutama yang terkait dengan penyelenggaraan kesehatan reproduksi remaja dan terkait upaya penurunan Angka Kematian Ibu (AKI). Di Provinsi Jateng, tingginya AKI telah menjadi salah satu fokus dalam RPJMD Tahun 2013-2018. Upaya yang dilakukan untuk menekan AKI antara lain dengan melaksanakan Program Desa Siaga Aktif, Program Rumah Tinggal Kelahiran, dan Rumah Singgah untuk ibu hamil. Ada pun di Provinsi Kalbar terdapat Peraturan Daerah No. 3 Tahun 2013 tentang Penyelenggaraan Kesehatan Reproduksi. Terkait hambatan dalam penyelenggaraan kesehatan reproduksi, di Provinsi Jateng pelaksanaan pelayanan kesehatan bagi ibu dan anak masih terhambat oleh belum terpenuhinya prasarana dan sarana serta belum meratanya pendayagunaan dan kompetensi tenaga kesehatan. Demikian pula dengan Provinsi Kalbar. Selain pelayanan kesehatan belum optimal, tingginya angka pernikahan dini menjadi salah satu masalah yang dihadapi dalam penyelenggaraan kesehatan reproduksi.
\end{abstract}

Kata kunci: Kesehatan Reproduksi, Angka Kematian Ibu, Peraturan Pemerintah Nomor 61 Tahun 2014, Provinsi Jawa Tengah, Provinsi Kalimantan Barat. 


\section{Pendahuluan}

Meningkatkan kesehatan ibu adalah salah satu butir dari Tujuan Pembangunan Milenium/ Millennium Development Goals (MDGs) yang harus dicapai oleh 191 negara anggota PBB pada tahun 2015, termasuk Indonesia, yaitu tujuan ke-5. Meningkatkan kesehatan ibu (selanjutnya disebut MDGs 5) terdiri dari dua target, yaitu: (1) mengurangi 2/3 Angka Kematian Ibu (AKI) saat melahirkan (1990-2015); dan (2) akses terhadap pelayanan kesehatan standar hingga tahun 2015 (Riset Kesehatan Dasar, 2010:175). Khusus untuk Indonesia, tujuan yang ditetapkan dalam MDGs 5 ada tiga poin, salah satu di antaranya adalah menurunkan AKI dari 390 per 100.000 kelahiran hidup pada tahun 1990 menjadi 102 per 100.000 kelahiran hidup pada tahun 2015 (Riset Kesehatan Dasar, 2010:175).

Terkaitdengan AKI,LaporanPencapaianMDGs Indonesia Tahun 2010 menunjukkan bahwa MDGs 5 Target 5A termasuk ke dalam kategori sasaran MDGs yang telah menunjukkan kecenderungan kemajuan yang baik namun masih memerlukan kerja keras untuk mencapainya (Badan Perencanaan Pembangunan Nasional, 2010:12). Data resmi dari Kementerian Perencanaan Pembangunan Nasional/ Bappenas menyatakan AKI telah menurun dari 390 per 100.000 kelahiran hidup pada tahun 1991 menjadi 228 per 100.000 kelahiran hidup pada tahun 2007 (Badan Perencanaan Pembangunan Nasional, 2010:84). Data ini berbeda dengan laporan dari United Nations Population Fund (UNFPA) yang menyatakan bahwa AKI di Indonesia pada tahun 2009 masih sebesar 420 per 100.000 kelahiran hidup (Suara Pembaruan, 27 Desember 2009:15). Hasil Survei Demografi Kesehatan Indonesia (SDKI) tahun 2012 menunjukkan AKI sebesar 359 per 100.000 kelahiran hidup, naik dari tahun 2007 (Kompas, 14 Maret 2015). Sedangkan data terakhir dari United Nations Development Programme (UNDP) yang terdapat dalam indeks pembangunan manusia/human development index tahun 2015 menunjukkan AKI di Indonesia masih sebesar 190 per 100.000 kelahiran hidup. ${ }^{1}$

Apabila melihat target dalam MDGs yaitu sebesar 102 per 100.000 kelahiran hidup pada tahun 2015, terlihat bahwa AKI di Indonesia masih belum sesuai dengan target tersebut. Kegagalan untuk mencapai target ini sudah diperkirakan sebelumnya oleh berbagai pihak terkait. Hasil penelitian Women

\footnotetext{
"Human Development Report 2015 Work for Human Development Briefing Note for Countries on the 2015 Human Development Report Indonesia, “ http://hdr.undp. org/sites/all/themes/hdr_theme/country-notes/IDN.pdf, diakses 7 Maret 2016.
}

Research Institute (WRI), sebuah lembaga swadaya masyarakat yang fokus terhadap isu perempuan menyimpulkan bahwa target penurunan AKI dalam MDGs tidak akan dapat dicapai (Kompas, 25 Juni 2011:42). Dengan prediksi linier AKI, Kementerian Kesehatan juga memperkirakan pada tahun 2015 Indonesia baru akan mencapai angka 161 per 100.000 kelahiran hidup (Media Indonesia, 8 Juli 2011:20).

Kegagalan beberapa target dalam MDGs di satu sisi dan berakhirnya masa berlaku MDGs pada akhir tahun 2015 di sisi yang lain kemudian memunculkan konsep dokumen Sustainable Development Goals (SDGs) yang menjadi acuan dalam perundingan negara-negara dunia untuk melanjutkan pembangunan pasca-MDGs. Konsep SDGs melanjutkan konsep MDGs sehingga tidak terpisah dari pencapaian MDGs dan merupakan bentuk penyempurnaan dari MDGs. SDGs dicanangkan untuk melanjutkan tujuan utama MDGs yang belum tercapai, antara lain permasalahan kesehatan ibu dan anak; akses terhadap air bersih dan sanitasi; kesetaraan gender dan pemberdayaan perempuan; dan status nutrisi. ${ }^{2}$

SDGs merupakan hasil akhir dari perundingan Open Working Group on Sustainable Development Goals (OWG) yang berlangsung selama satu setengah tahun. OWG beranggotakan 193 negara dengan sistem troika untuk pengambilan suara yakni 1 suara untuk 3 negara, Indonesia berbagi suara dengan Republik Tiongkok dan Kazakhstan. Karena telah melibatkan seluruh negara anggota PBB, SDGs dianggap sebagai dokumen yang komprehensif dan inklusif. Dokumen SDGs disahkan pada Sidang Umum PBB ke-69 tanggal 23 September 2014. Dokumen berisi 17 tujuan SDGs dan 169 indikator yang harus dipenuhi. Dalam SDGs, target penurunan AKI secara global pada tahun 2030 adalah 70 per 100.000 kelahiran hidup. ${ }^{3}$

Upaya penurunan AKI berkaitan erat dengan pelayanan kesehatan reproduksi. Masalah kesehatan reproduksi ini telah diatur dalam Undang-Undang Nomor 36 Tahun 2009 tentang Kesehatan. Selanjutnya untuk melaksanakan amanat undangundang tersebut, Pemerintah mengeluarkan Peraturan Pemerintah (PP) Nomor 61 Tahun

\footnotetext{
2 "SDGs gantikan MDGs sebagai acuan perundingan pembangunan", http://www.antaranews.com/ berita/453769/ sdgs-gantikan-mdgs-sebagai-acuan-perundinganpembangunanSDGs, diakses 5 Maret 2015.

Republika Rabu, 16 Desember 2015, 21:55 WIB “Angka Kematian Ibu di Indonesia Masih Tinggi”, http:// nasional.republika.co.id/berita/nasional/umum/15/12/16/ nzghga383-angka-kematian-ibu-di-indonesia-masihtinggi), diakses 7 Januari 2016.
} 
2014 tentang Kesehatan Reproduksi. PP tersebut sebagian besar mengatur mengenai kesehatan ibu, yaitu sebanyak 23 pasal. Dapat dikatakan pasal yang mengatur tentang kesehatan ibu ini merupakan hal yang paling penting dalam PP tersebut, karena bergerak dari hulu dengan menjamin perempuan agar mendapat pelayanan kesehatan yang baik. Pelayanan kesehatan yang dimaksud termasuk pelayanan kesehatan reproduksi sedini mungkin, yaitu sejak remaja. Pelayanan itu diberikan melalui layanan kesehatan reproduksi remaja, kesehatan masa pra-kehamilan, selama kehamilan, persalinan, pasca-melahirkan, layanan kontrasepsi, kesehatan seksual, dan kesehatan sistem reproduksi.

Pelayanan kesehatan reproduksi yang berkaitan dengan pemeriksaan selama masa kehamilan, persalinan, dan penggunaan alat kontrasepsi ini merupakan salah satu faktor yang berpengaruh terhadap AKI. Rendahnya kualitas pelayanan kesehatan reproduksi dengan demikian menjadi salah satu faktor yang dapat menghambat upaya penurunan AKI yang menjadi salah satu target MDGs. Saat ini masih terdapat 64 kabupaten/kota di 9 provinsi yang memiliki tingkat kematian ibu yang tinggi (Media Indonesia, 9 Januari 2015).

Dalam PP Nomor 61 Tahun 2014 pelayanan kesehatan reproduksi tidak hanya menjadi tanggung jawab pemerintah, melainkan juga pemerintah daerah, baik pemerintah provinsi maupun kabupaten/kota. Berdasarkan latar belakang tersebut di atas, dapat dirumuskan permasalahan sebagai berikut: "Bagaimana peran pemerintah daerah dalam penyelenggaraan kesehatan reproduksi?" Permasalahan tersebut kemudian dijabarkan dalam dua pertanyaan penelitian berikut: (1) Bagaimana kebijakan pemerintah daerah terkait dengan penyelenggaraan kesehatan reproduksi, termasuk di dalamnya implementasi Peraturan Pemerintah Nomor 61 Tahun 2014 tentang Kesehatan Reproduksi; (2) Apa hambatan yang dihadapi oleh pemerintah daerah dalam penyelenggaraan kesehatan reproduksi?

Penelitian ini bertujuan untuk: (1) mendapatkan gambaran umum mengenai kebijakan pemerintah daerah terkait dengan penyelenggaraan kesehatan reproduksi; (2) mengetahui hambatan yang dihadapi oleh pemerintah daerah dalam penyelenggaraan kesehatan reproduksi. Hasil penelitian ini diharapkan dapat menjadi bahan masukan bagi Anggota DPR khususnya Komisi VIII dan Komisi IX dalam melaksanakan fungsi pengawasan yang berkaitan dengan kebijakan pemerintah di bidang kesehatan reproduksi. Selain itu, hasil penelitian dapat menjadi bahan masukan dalam pembahasan RUU tentang Kesetaraan Gender yang terkait dengan hak reproduksi, mengingat RUU ini termasuk dalam daftar prioritas Program Legislasi Nasional (Prolegnas) Tahun 2015-2019.

Secara umum penelitian ini menggunakan pendekatan kualitatif. Pendekatan ini dipilih karena sifat pendekatan kualitatif yang terbuka dan fleksibel. Melalui pendekatan ini diharapkan dapat diperoleh masukan sebanyak-banyaknya dari para narasumber dan informan, sehingga dapat diperoleh gambaran yang utuh mengenai peran pemerintah daerah dalam penyelenggaraan kesehatan reproduksi perempuan.

Sesuai dengan pendekatan yang dipakai, yaitu pendekatan kualitatif, data dikumpulkan melalui wawancara terbuka kepada narasumber dan informan penelitian. Sejalan dengan metode pengumpulan data yang digunakan, yaitu wawancara mendalam dan studi dokumen yang relevan dengan topik penelitian, terutama kepada pejabat di instansi atau Satuan Kerja Perangkat Daerah (SKPD) yang menangani bidang pemberdayaan perempuan, bidang keluarga berencana, dan bidang kesehatan. Data yang telah terkumpul melalui serangkaian teknik pengumpulan data tersebut dianalisis secara kualitatif.

Penelitian dilaksanakan di Provinsi Kalimantan Barat (Kalbar) dan Provinsi Jawa Tengah (Jateng). Provinsi Kalbar dipilih karena provinsi ini telah memiliki peraturan daerah yang mengatur tentang penyelenggaraan kesehatan reproduksi jauh sebelum diterbitkannya PP Nomor 61 Tahun 2014, yaitu Peraturan Daerah Provinsi Kalimantan Barat Nomor 3 Tahun 2013 tentang Penyelenggaraan Kesehatan Reproduksi. Ada pun Provinsi Jateng dipilih karena meskipun belum memiliki perda yang mengatur tentang kesehatan reproduksi, namun selama tiga tahun berturut-turut provinsi ini menjadi salah satu penerima Anugerah Parahita Ekapraya dari Kementerian Pemberdayaan Perempuan dan Perlindungan Anak karena telah berkomitmen dan mengimplementasikan strategi pengarusutamaan gender dan pemenuhan hak anak di berbagai sektor pembangunan, yaitu pada tahun 2011, 2012, dan 2013. Penelitian dilaksanakan selama 5 hari masingmasing tanggal 8-12 Juni 2015 di Provinsi Jateng dan tanggal 3-7 Agustus 2015 di Provinsi Kalbar.

\section{Kesehatan Reproduksi Perempuan}

Kesehatan reproduksi dalam arti luas meliputi seluruh proses, fungsi, dan sistem reproduksi pada seluruh tahapan kehidupan manusia (Muhadjir Darwin, 1996:2). Proses reproduksi berawal dari sebelum terjadi konsepsi, sebelum terjadi pembuahan oleh sperma terhadap sel telur, kemudian terjadi konsepsi, hamil, lahir, bayi, 
remaja, usia produktif dan usia lanjut. Dengan demikian kesehatan reproduksi dimulai sejak masa remaja hingga usia lanjut (Muhammad, 1996 sebagaimana dikutip Suryawati, 2007:22).

Pada masa remaja, perilaku seksual yang tidak sehat dapat menyebabkan Kasus Kehamilan Tidak Diinginkan (KTD) yang selanjutnya memicu praktik aborsi yang tidak aman, penularan Penyakit Menular Seksual (PMS) dan HIV/AIDS, bahkan kematian (DeLamater, 2007 sebagaimana dikutip Azinar, 2013:154). Ada pun pada masa dewasa, permasalahan yang paling menonjol dalam kesehatan reproduksi adalah masih tingginya AKI. Menurut Departemen Kesehatan (1998) sebagaimana dikutip Jekti dan D. Mutiatikum (2011:85), penyebab utama AKI di Indonesia sebagian besar (lebih dari 90 persen) adalah trias classic, yaitu perdarahan (4060 persen), toksemiagravidarum (20-30 persen), dan infeksi (20-30 persen).

Isu tentang kesehatan reproduksi perempuan telah diakui secara internasional sejak Deklarasi Hak Asasi Manusia Tahun 1968 di Teheran, berlanjut dengan Deklarasi Meksiko Tahun 1975 sebagai hasil Konferensi Wanita se-Dunia ke-1, dan diperkuat dengan Konferensi Wanita se-Dunia ke-2 di Kopenhagen, ke-3 di Nairobi dan ke-4 di Beijing. Hak perempuan atas kesehatan reproduksi juga dijamin dalam Pasal 12 Konvensi tentang Penghapusan Segala Bentuk Diskriminasi terhadap Perempuan (Convention on the Elimination of All Forms of Discrimination against Women/CEDAW) yang telah diratifikasi dengan Undang-undang Nomor 7 Tahun 1984 tentang Pengesahan Konvensi mengenai Penghapusan Segala Bentuk Diskriminasi terhadap Wanita pada tanggal 24 Juli 1984.

Berbagai persoalan yang dialami oleh perempuan dalam bidang kesehatan merupakan salah satu faktor yang memunculkan pemikiran baru yang berorientasi melindungi hak reproduksi perempuan. Badan Kesehatan Dunia (World Health Organization/WHO) memberikan definisi bahwa kesehatan reproduksi menyangkut proses, fungsi, dan sistem reproduksi pada seluruh tahap kehidupan (Budi Wahyuni, 1997:55). Mengacu pada definisi tersebut, Konferensi Internasional tentang Kependudukan dan Pembangunan (International Conference on Population and Development/ ICPD) tahun 1994 di Kairo, Mesir, merumuskan kesehatan reproduksi sebagai "keadaan sehat dan sejahtera secara fisik, mental, dan sosial bukan karena ketiadaan penyakit dan kecacatan yang berkaitan dengan fungsi, sistem, dan prosesprosesnya" (Rahman, 2006:520). Konsep Kesehatan Reproduksi yang diperkenalkan dalam ICPD di Kairo tersebut menurut Suryawati (2007:22) menekankan kondisi kesehatan yang lengkap, tidak hanya terbebas dari penyakit atau kelemahan fisik, melainkan juga meliputi aspek mental dan sosial, yang berkorelasi dengan bekerjanya fungsi sistem serta proses reproduksi. Indonesia merupakan salah satu negara peserta dalam konferensi ICPD. Konferensi tersebut menghasilkan keputusan yang terdiri atas 10 program kesehatan reproduksi, berupa kesehatan primer yang harus diperhatikan oleh semua negara, termasuk Indonesia, antara lain (Rahman, 2006:521):

a. Pelayanan sebelum, semasa kehamilan, dan pascakehamilan;

b. Pelayanan keluarga berencana yang optimal;

c. Pelayanan aborsi; dan

d. Pelayanan dan pemberian Komunikasi, Informasi, dan Edukasi (KIE) yang berkaitan dengan kesehatan reproduksi.

Di samping 10 program kesehatan reproduksi tersebut dalam Deklarasi ICPD juga diakui adanya hak reproduksi perempuan, yaitu (Rahman, 2006:521):

a. Hak individu untuk menentukan kapan ia akan mempunyai anak, berapa jumlah anak, dan berapa lama jarak tiap kelahiran;

b. Hak untuk mendapat pelayanan yang berkaitan dengan fungsi reproduksinya;

c. Hak untuk mendapatkan KIE yang berkaitan dengan hak tersebut; dan

d. Hak melakukan kegiatan seksual tanpa paksaan, diskriminasi, dan kekerasan.

Keempat hak reproduksi ini dikukuhkan lagi dalam Deklarasi Beijing Tahun 1995 dalam Pasal 96. Tujuan utama dua kesepakatan internasional tersebut adalah untuk mengurangi AKI dan kesakitan atau kecacatan akibat aborsi yang tidak aman (Rahman, 2006:521).

\section{Faktor yang Memengaruhi Kesehatan Reproduksi Perempuan}

Masalah yang berkaitan dengan kehamilan dan persalinan, termasuk AKI tidak dapat dilepaskan dari berbagai faktor yang memengaruhinya, antara lain derajat kesehatan ibu dan kesiapan untuk hamil, pemeriksaan antenatal (masa kehamilan), pertolongan persalinan dan perawatan segera setelah persalinan, serta faktor sosial budaya (Poerwandari dan Akmal, 2000:436). Dalam konteks Indonesia, terbatasnya akses perempuan terhadap fasilitas pelayanan kesehatan reproduksi yang berkualitas, terutama bagi perempuan miskin di Daerah Tertinggal, Perbatasan dan Kepulauan (DTPK) merupakan salah satu tantangan yang dihadapi dalam pencapaian MDGs 5 Target 5A 
(Badan Perencanaan Pembangunan Nasional, 2010:90). Penyediaan fasilitas PONEK, PONED, Posyandu, dan unit transfusi darah belum merata dan belum seluruhnya terjangkau oleh seluruh penduduk. Sistem rujukan dari rumah ke Puskesmas dan ke rumah sakit juga belum berjalan dengan optimal. Faktor lain yang memengaruhi tingginya AKI adalah akses jalan yang buruk ke tempat pelayanan kesehatan (Kompas, 25 Juni 2011:42). Hal itu masih ditambah dengan faktor budaya di daerah tertentu (Badan Perencanaan Pembangunan Nasional, 2010:90).

Secara lebih rinci, analisis yang dilakukan oleh WHO terhadap kaitan antara gender dan kesehatan menunjukkan adanya berbagai faktor yang berdampak terhadap status kesehatan perempuan, yaitu:

a. Perbedaan biologis, meliputi:

(1) anatomis;

(2) fisiologis;

(3) genetik; dan

(4) sistem imunitas.

b. Perbedaan sosial budaya, meliputi:

(1) peran dan tanggung jawab;

(2) norma (adat dan agama);

(3) ekspektasi masyarakat/keluarga; dan

(4) identitas subjektif.

c. Akses dan kontrol terhadap sumber daya, meliputi:

(1) ekonomi;

(2) sosial;

(3) politik;

(4) ketersediaan dan kualitas informasi dan edukasi tentang kesehatan reproduksi;

(5) ketersediaan waktu untuk berpartisipasi dalam program kesehatan;

(6) ketersediaan dan kualitas layanan;

(7) keterbatasan sumber daya internal;

(8) otoritas terhadap tubuh sendiri untuk memilih layanan yang diinginkan; dan

(9) kontrol atas pengambilan keputusan dan keterampilan untuk mencegah komplikasi penyakit.

\section{Penyelenggaraan Kesehatan Reproduksi di Indonesia}

Sistem kesehatan di Indonesia terdiri dari pelayanan kesehatan yang disediakan oleh pihak swasta dan pemerintah atau dikenal dengan istilah pelayanan kesehatan publik atau masyarakat (Mundayat, dkk, 2010:325). Kementerian Kesehatan dan pemerintah di tingkat lokal bertanggung jawab untuk menyediakan pelayanan publik dalam bidang kesehatan, termasuk membuat peraturan dan memberikan akreditasi kepada pihak swasta dalam memberikan pelayanan kesehatan. Berdasarkan Undang-Undang Nomor 23 Tahun 2014 tentang Pemerintahan Daerah Pasal 12 ayat (1), bidang kesehatan merupakan salah satu bidang urusan pemerintahan wajib yang berkaitan dengan pelayanan dasar yang menjadi kewenangan pemerintah daerah.

Kebijakan tentang kesehatan diatur dalam Undang-Undang Nomor 36 Tahun 2009 tentang Kesehatan. Dalam undang-undang ini diatur beberapa isu penting mengenai kesehatan reproduksi perempuan seperti aborsi, penggunaan kontrasepsi serta kesehatan ibu, bayi, dan anak. Namun demikian sesuai dengan Pasal 72 huruf a dan $b$, pengaturan ini hanya berlaku bagi pasangan yang sah atau yang secara resmi menikah dan tidak bertentangan dengan norma-norma agama (Mundayat, dkk, 2010:325).

Salah satu peraturan pelaksana dari UndangUndang Nomor 36 Tahun 2009 tentang Kesehatan adalah Peraturan Pemerintah Nomor 61 Tahun 2014 tentang Kesehatan Reproduksi. Dalam Pasal 6 huruf a PP tersebut dinyatakan bahwa pemerintah daerah provinsi bertanggung jawab terhadap penyelenggaraan dan fasilitasi pelayanan, program, bimbingan, dan koordinasi di bidang kesehatan reproduksi dalam lingkup provinsi dan lintas kabupaten/kota dalam provinsi. Demikian pula di tingkat kabupaten/kota. Pasal 7 huruf a juga menyatakan bahwa pemerintah daerah kabupaten/ kota bertanggung jawab terhadap penyelenggaraan dan fasilitasi pelayanan kesehatan reproduksi di fasilitas pelayanan kesehatan dasar dan rujukan lingkup kabupaten/kota;

Ruang lingkup pelayanan kesehatan reproduksi dalam PP secara lebih rinci diatur dalam Pasal 8 ayat (3) yang meliputi: a. pelayanan kesehatan reproduksi remaja; b. pelayanan kesehatan masa sebelum hamil, hamil, persalinan, dan sesudah melahirkan; c. pengaturan kehamilan, pelayanan kontrasepsi dan kesehatan seksual; dan d. pelayanan kesehatan sistem reproduksi. Selanjutnya pada ayat (4) pasal tersebut dinyatakan bahwa pelayanan kesehatan sebagaimana dimaksud pada ayat (3) dilaksanakan melalui pendekatan promotif, preventif, kuratif, dan rehabilitatif.

Dalam implementasinya, penyelenggaraan kesehatan reproduksi perempuan di Indonesia masih menghadapi berbagai hambatan. Mengutip BKKBN (1998), Chriswardani Suryawati (2007:22) menyatakan kendala dalam pelaksanaan kegiatan yang berkaitan dengan kesehatan reproduksi antara lain: (1) adanya realita tentang kurangnya kesatuan pengertian tentang kesehatan reproduksi; (2) kurang tersedianya infrastruktur di setiap kabupaten/kota; 
(3) adanya variasi geografis, aspek sosial budaya; dan (4) tingkat sosial ekonomi yang relatif terbatas.

Kondisi sosial budaya (adat istiadat) dan kondisi lingkungan (kondisi geografis) sebagai faktor yang berpengaruh terhadap kesehatan reproduksi juga ditekankan oleh Muhammad (1996) sebagaimana dikutip oleh Suryawati (2007:23) yang menyatakan bahwa situasi budaya dalam hal ini adat istiadat saat ini memang tidak kondusif untuk help seeking behavior dalam masalah kesehatan reproduksi. Lebih lanjut Suryawati (2007:23) menyatakan bahwa sebagian besar masyarakat Indonesia masih menganggap bahwa kehamilan merupakan suatu hal yang wajar yang tidak memerlukan asuhan antenal.

\section{Kebijakan Pemerintah Daerah dalam Penyelenggaraan Kesehatan Reproduksi Provinsi Jawa Tengah}

Kebijakan Pemerintah Provinsi Jateng terkait dengan kesehatan reproduksi secara umum dapat dilihat dari Rencana Pembangunan Jangka Menengah Daerah (RPJMD) Provinsi Jateng yang ditetapkan melalui Peraturan Daerah Provinsi Jawa Tengah Nomor 5 Tahun 2014 tentang Rencana Pembangunan Jangka Menengah Daerah (RPJMD) Provinsi Jawa Tengah Tahun 2013-2018. Dalam dokumen tersebut, kebijakan tentang kesehatan reproduksi tidak dapat dipisahkan dari kondisi demografis Provinsi Jateng secara keseluruhan, yang dicantumkan dalam Bab II RPJMD tentang Gambaran Umum Kondisi Daerah.

Masalah AKI sebagai bagian dari masalah kesehatan reproduksi perempuan telah menjadi salah satu fokus perhatian Pemerintah Provinsi Jateng. AKI menjadi salah satu aspek kesejahteraan masyarakat yang dipaparkan dalam Bab II. Dinyatakan bahwa kecenderungan AKI dalam kurun waktu 5 tahun mengalami peningkatan dari 114,42 per 100.000 kelahiran hidup pada tahun 2008 menjadi 116,34 per 100.000 kelahiran hidup pada tahun 2012. Apabila dibandingkan angka nasional (SDKI Tahun 2012), angka ini masih berada di bawah angka nasional sebesar 359 per 100.000 kelahiran hidup.

Penyebab tertinggi AKI di provinsi ini antara lain hipertensi, pendarahan, masih rendahnya deteksi dini kehamilan risiko tinggi oleh masyarakat dan masih kurangnya kesiapsiagaan keluarga dalam rujukan persalinan pada kehamilan risiko tinggi. Kondisi ini menggambarkan derajat kesehatan masyarakat khususnya status kesehatan ibu masih perlu ditingkatkan, terutama di wilayah-wilayah dengan kasus kematian ibu tinggi, antara lain di Kabupaten Brebes, Tegal, Pemalang, Cilacap, Grobogan, Banyumas, Pekalongan, dan Batang.
Kebijakan Pemerintah Provinsi Jateng yang telah berperspektif gender tidak lepas dari kebijakan di bidang pemberdayaan perempuan dan perlindungan anak. Dalam rangka mewujudkan kebijakan, program, dan kegiatan yang responsif gender di Provinsi Jateng, secara sistematis telah dilakukan langkahlangkah mengintegrasikan perspektif gender ke dalam dokumen perencanaan mulai dari RPJMD, Rencana Strategis (Renstra) SKPD, dan Rencana Kerja (Renja) SKPD. Dokumen RPJMD Tahun 2013-2018 telah mengintegrasikan isu gender ke dalam penjelasan misi dan kebijakan. Selain itu, beberapa isu gender telah terintegrasi di dalam Renstra SKPD, antara lain pada Renstra Dinas Tenaga Kerja, Transmigrasi dan Kependudukan; Dinas Pendidikan; serta Dinas Peternakan dan Kesehatan Hewan. Terkait dengan penyusunan dokumen RKPD, isu gender telah terintegrasi sejak Tahun 2008. Selain dokumen perencanaan, produk kebijakan yang dihasilkan antara lain: (1) KUA-PPAS yang responsif gender; (2) Surat Edaran Gubernur Jawa Tengah tentang Pedoman Penyusunan RKA SKPD dan RBA RSUD-RSJD; (3) Surat Edaran Gubernur tentang Penyusunan Perencanaan dan Penganggaran yang Responsif Gender, serta (4) Peraturan Gubernur tentang Panduan Teknis Pelaksanaan Pengarusutamaan Gender di Provinsi Jawa Tengah.

Kebijakan tentang kesehatan reproduksi juga terkait dengan kebijakan di bidang keluarga berencana dan keluarga sejahtera. Angka Contraceptive Prevalence Rate (CPR)/Peserta KB Aktif dari tahun ke tahun cenderung meningkat, walaupun kenaikannya tidak begitu besar, yaitu dari 4,9 juta pada tahun 2008 menjadi 5,4 juta pada tahun 2012. Data selengkapnya dapat dilihat pada Tabel 1.

Tabel 1. Peserta KB Aktif

Provinsi Jawa Tengah Tahun 2008 - 2012

\begin{tabular}{cccc}
\hline Tahun & Jumlah PUS & $\begin{array}{c}\text { Peserta KB } \\
\text { Aktif }\end{array}$ & $\%$ \\
\hline 2008 & 6.357 .836 & 4.964 .579 & 78,09 \\
2009 & 6.487 .025 & 5.080 .590 & 78.32 \\
2010 & 6.561 .254 & 5.155 .761 & 78.58 \\
2011 & 6.683 .596 & 5.285 .530 & 79.08 \\
2012 & 6.738 .688 & 5.403 .576 & 80.19 \\
\hline
\end{tabular}

Sumber: BKKBN Provinsi Jawa Tengah, 2013.

Ada pun bila dilihat dari persentase drop out, peserta $\mathrm{KB}$ dari tahun ke tahun mengalami kenaikan, dari 11,46 persen pada tahun 2008 meningkat menjadi 15,09 persen pada tahun 2012. Peningkatan tersebut dikarenakan antara lain masih rendahnya komitmen kabupaten/kota terhadap program KB, belum mantapnya kelembagaan, rasio 
PLKB terhadap desa/kelurahan yang ditangani belum proporsional, dan masih banyak akseptor menggunakan alat kontrasepsi non-Metode Kontrasepsi Jangka Panjang (MKJP).

Sedangkan bila dilihat dari Unmet Need, yaitu Pasangan Usia Subur (PUS) yang tidak ingin mempunyai anak lagi atau ingin menunda kelahiran berikutnya tetapi tidak menggunakan alat atau cara $\mathrm{KB}$ atau kebutuhan $\mathrm{KB}$ yang tidak terpenuhi, persentase Unmet Need KB masih cukup tinggi walaupun dari tahun ke tahun mengalami penurunan, yaitu sebesar 12,44 persen pada tahun 2008 menjadi 10,26 persen pada tahun 2012.

Peran serta masyarakat dalam layanan KB mandiri sangat diperlukan bagi suksesnya pengendalian penduduk di Jateng. Kepesertaan KB Mandiri selama kurun waktu tahun 2008-2012 fluktuatif. Prevalensi Akseptor KB (KB Aktif) persentasenya senantiasa meningkat dari tahun ke tahun, hal ini disebabkan bertambahnya akseptor KB. Jumlah peserta KB aktif dari tahun ke tahun mengalami kenaikan, walaupun kenaikannya tidak begitu besar, yaitu dari 4,9 juta orang pada tahun 2008 menjadi 5,4 juta orang pada tahun 2012. Pada tahun 2008 akibat pengaruh transisi era otonomi daerah dan komitmen pemerintah kabupaten/kota dalam program $\mathrm{KB}$, terlihat bahwa jumlah peserta $\mathrm{KB}$ aktif mengalami penurunan walaupun relatif kecil. Secara keseluruhan jumlah peserta KB aktif dari tahun ke tahun mengalami kenaikan, karena persentase PUS yang mengikuti Program KB di Jateng cukup tinggi, yaitu setiap 100 PUS rata-rata 70 sampai dengan 80 PUS yang mengikuti Program KB. Kondisi seperti ini merupakan tantangan yang cukup berat bagi Jateng, karena harus menjaga atau memelihara peserta KB aktif dalam jumlah yang besar agar tidak terjadi drop out.

Upaya untuk menurunkan AKI dilaksanakan melalui peningkatan pelayanan kesehatan ibu dan anak di Puskemas PONED (Pelayanan Obstetri Neonatal Emergensi Dasar) dan Rumah Sakit PONEK (Pelayanan Obstetri Neonatal Emergensi Komprehensif). Kebijakan untuk menurunkan AKI yang terdapat dalam RPJMD tersebut selanjutnya dijabarkan lebih rinci dalam Renstra Dinas Kesehatan (Dinkes).

Terkait dengan kesehatan reproduksi remaja, dari wawancara dengan Kepala Seksi Kesehatan Keluarga, Ibu, Anak, Lansia, dan Gizi Dinkes Provinsi Jateng beserta staf tanggal 9 Juni 2015 dinyatakan bahwa kesehatan reproduksi remaja termasuk dalam program kesehatan anak. Untuk peserta KB aktif, BKKBN menyediakan alat kontrasepsi dan sarana dan prasarananya, termasuk Intra Uterine Device (IUD).
Salah satu kegiatan yang dilakukan adalah Program Rumah Singgah untuk menurunkan AKI, yaitu bagi ibu hamil yang terlambat ditangani yang diluncurkan pada tanggal 10 Juni 2015. Acara dibuka oleh Direktorat Jenderal Pembinaan Kesehatan Ibu dan Anak Kementerian Kesehatan. Rumah Singgah bertujuan agar ibu hamil tidak terlambat ditangani. Rumah Singgah ini akan diinisiasi di 5 kabupaten, yaitu: Cilacap, Temanggung, Wonosobo, Banjarnegara, dan Jepara. SKPD di kabupaten yang akan terlibat dan berperan dalam program ini adalah Dinkes, Bappeda, Biro Kesra, dan Biro Keuangan. Selain itu, juga telah terdapat Program Rumah Tinggal Kelahiran, yang sudah dilaksanakan di beberapa kabupaten/kota, antara lain Banjarnegara, Cilacap (persalinan di Puskesmas) dan Tegal (wilayah di mana AKI masih tinggi).

Bagi ibu hamil ada Program Kelas Ibu, yaitu pendidikan untuk ibu hamil yang dipersiapkan untuk meningkatkan pengetahuan dan keterampilan ibu sebelum melahirkan. Program ini sudah ada di setiap desa, tetapi belum di setiap Posyandu. Kelas Ibu merupakan program dari pusat (Kementerian Kesehatan).

Sejak tahun 2011 ada kebijakan daerah bahwa dukun tidak boleh menangani persalinan. Dukun hanya sebagai mitra bidan, dan diarahkan untuk pijat bayi setelah bayi lahir. Di setiap kabupaten hal itu sudah dilaksanakan sejak tahun 2011. Tetapi data Dinkes tahun 2014 menunjukkan bahwa di seluruh provinsi masih terdapat 6 persalinan yang ditolong oleh dukun. Hal itu tidak terlepas dari berbagai kondisi, seperti faktor geografis dan jarak dengan fasilitas kesehatan. Selain itu, juga ada kebijakan pertolongan persalinan 4 tangan (persalinan minimal ditangani oleh dua orang).

Dari sisi umur, kehamilan yang ideal adalah di atas 20 tahun dan sebelum 30 tahun, karena kehamilan di bawah 20 tahun dan di atas 30 tahun termasuk ke dalam kehamilan risiko tinggi. Tetapi data di provinsi ini menunjukkan bahwa AKI tertinggi adalah ibu hamil berusia 20-35 tahun. Hal ini kemungkinan disebabkan karena jumlah ibu hamil dalam usia tersebut juga lebih banyak dibanding ibu hamil yang berusia kurang dari 20 tahun dan lebih dari 35 tahun.

Dari narasumber di Dinkes juga diketahui bahwa sudah ada Peraturan Gubernur tentang Pengendalian Penduduk dan Keluarga Berencana. Selain itu, sedang dirancang Perda tentang ASI Eksklusif dan Perda tentang Rencana Aksi Daerah tentang MDGs. Saat ini konsep sudah hampir final di tingkat pemerintah daerah dan akan segera disampaikan kepada Biro Hukum Pemerintah Provinsi Jateng. 
Terkait dengan kebijakan dalam bentuk peraturan, di salah satu desa di Banjarnegara terdapat peraturan desa yang mengatur tentang persalinan yang harus ditolong oleh tenaga kesehatan dan denda bagi yang melanggar dengan membayar biaya sebesar biaya persalinan bila ditolong oleh tenaga kesehatan. Uang yang terkumpul kemudian masuk ke kas desa.

Menurut narasumber, masalah kesehatan reproduksiadalahmasalahyang bersifatlintas sektordan tidak dapat ditangani oleh Dinkes saja. Apabila hanya Dinkes yang menangani, maka hasilnya akan sangat lambat dan lama baru terlihat. Selain itu, masyarakat juga turut berperan dalam keberhasilan programprogram kesehatan reproduksi, sehingga masyarakat juga harus berpartisipasi. Misalnya yang menyangkut tentang Female Genital Mutilation (FGM). Guru juga berperan penting dalam mensosialisasikan kesehatan reproduksi, misalnya usia melahirkan yang ideal. Dinkes telah melakukan perencanaan dan evaluasi tingkat seksi dengan mengundang pihak Kantor Wilayah Kementerian Agama dan Dinas Pendidikan. Salah satu contoh program adalah pemberian tablet tambah darah bagi remaja puteri mulai tingkat SMP di beberapa kabupaten/kota.

Pendidikan kesehatan reproduksi perlu disampaikan di sekolah, tetapi harus dikemas sesuai dengan usia siswa. Untuk itu peran guru sangat penting, sehingga diperlukan pelatihan guru mengenai kesehatan reproduksi. Diusulkan agar Kementerian Pendidikan dan Kebudayaan serta Kementerian Kesehatan bekerja sama untuk melaksanakan program tersebut. Saat ini telah ada Program Buku Kesehatanku untuk siswa sekolah SMP dan SMA dari Kementerian Kesehatan. Program ini terbukti efektif untuk mengenalkan siswa kepada hak kesehatan reproduksi. Sebagai contoh, kasus di Provinsi Aceh. Ada siswa yang setelah membaca buku tersebut menjadi mengerti bahwa jenis kelaminnya berbeda.

Ada pun contoh kerja sama dengan Kanwil Kementerian Agama (Kemenag) yaitu adanya ketentuan bahwa calon pengantin harus suntik anti tetanus (TT) sebagai salah satu syarat untuk mendapatkan surat sehat dan menikah di KUA. Selain harus imunisasi TT, calon pengantin perempuan juga perlu diperiksa kadar hemoglobin untuk mengetahui apakah yang bersangkutan mengalami anemia atau tidak, dan periksa urin (untuk mengetahui status kehamilan). Selain itu, juga perlu dilakukan konseling pernikahan bagi calon pengantin. Saat ini hal tersebut sudah tidak dijalankan di semua KUA, tergantung pegawai KUA, sementara di tingkat Kemenag Provinsi masih dijalankan.
Kerja sama lainnya adalah dengan Badan Pemberdayaan Perempuan, Perlindungan Anak dan Keluarga Berencana (BP3AKB) dan Dinas Sosial dalam menangani kekerasan terhadap anak. Untuk menangani korban kekerasan, di setiap Puskesmas sudah disediakan petugas kesehatan yang menangani korban kekerasan.

Salah satu misi Dinkes Provinsi Jateng yaitu: melaksanakan pelayanan kesehatan yang bermutu dan berkeadilan. Adapun salah satu sasaran Dinkes yaitu: terwujudnya peningkatan akses masyarakat akan pelayanan kesehatan yang bermutu dan tertanganinya kasus atau permasalahan kesehatan pada kelompok masyarakat rentan, daerah perbatasan, dan terpencil. Terkait dengan misi dan sasaran tersebut, khusus untuk meningkatkan taraf kesehatan wilayah perdesaan, Dinkes Provinsi Jateng mengembangkan Desa Siaga Aktif.Pelayanan dasar bagi masyarakat desa yang meliputi upaya promotif, preventif, dan kuratif yang dilaksanakan oleh tenaga kesehatan (bidan) dan melibatkan kader atau tenaga sukarela lainnya, merupakan Upaya Kesehatan Bersumber Daya Masyarakat (UKBM), sebagai sarana pelayanan dasar bagi masyarakat desa. Untuk itu perlu penekanan terhadap fungsi dari Desa Siaga yang mencakup komponen Poliklinik Kesehatan Desa (PKD).

Menurut Kepala Dinkes Provinsi Jateng dengan Desa Siaga ini diharapkan masyarakat mempunyai kemandirian dalam mengatasi masalah kesehatan yang ada di wilayahnya serta secara aktif melakukan deteksi dini terhadap faktor-faktor yang mempunyai resiko untuk timbulnya masalah kesehatan, hingga pada akhirnya masyarakat di Desa Siaga Aktif mempunyai daya atau kemampuan untuk mengidentifikasi faktor resiko yang dapat menimbulkan masalah kesehatan, serta mempunyai kemampuan untuk mencegah dan menanggulangi faktor risiko tersebut. Pengembangan Desa Siaga Aktif merupakan langkah strategis untuk menangani masalah kematian ibu dan bayi, penyakit menular, dan sebagainya dengan mengikutsertakan masyarakat melalui upaya-upaya pemberdayaan. Oleh karena itu, pengembangan Desa Siaga Aktif memerlukan langkah-langkah edukatif, yaitu upaya mendampingi atau memfasilitasi masyarakat untuk melaksanakan proses pembelajaran berupa identifikasi masalah kesehatan dan faktor risiko di wilayahnya dan bagaimana proses pemecahannya, diiringi dengan komitmen pemangku kepentingan mulai tingkat provinsi, kabupaten/kota, kecamatan, dan desa/ kelurahan. ${ }^{4}$

"Pengembangan Desa Siaga Aktif," http://www. dinkesjatengprov.go.id/v2015/index.php/39-rokcontent/ frontpage/111-pengembangan-desa-siaga-aktif, diakses 18 Juni 2015. 
Kegiatan pengembangan Desa Siaga Aktif dilakukan antara lain dengan pertemuan pengembangan Desa Siaga Aktif melalui video conference dengan BPTPK Gombong sebagai tempat berlangsungnya kegiatan tersebut. Kegiatan ini diikuti oleh komponen Forum Kesehatan Desa/Kelurahan (FKD). Beberapa materi yang disampaikan antara lain permasalahan kompleks yang ada di Provinsi Jateng yang meliputi tingginya angka kematian ibu dan bayi; dan tingginya angka kesakitan dan angka kematian akibat penyakit menular (DBD, HIV/AIDS, diare, dan sebagainya) khususnya di tingkat desa/kelurahan. Pada sesi akhir pertemuan Kepala Dinkes memberikan beberapa instruksi, antara lain: (1) Meningkatkan komitmen dan dukungan pembangunan bidang kesehatan dalam menyikapi Undang-Undang Nomor 6 Tahun 2014 tentang Desa serta Peraturan Pemerintah Nomor 43 Tahun 2014 tentang Peraturan Pelaksanaan UU Nomor 6 Tahun 2014 tentang Desa dari kepala desa/lurah, bidan desa, Tim Penggerak PKK dan pihak lain terkait untuk mewujudkan kesejahteraan masyarakat; (2) Membangun, memantapkan, dan meningkatkan peran dan fungsi FKD sebagai motor penggerak pengembangan Desa Siaga Aktif dengan melakukan upaya-upaya pemberdayaan masyarakat guna meningkatkan kemandirian masyarakat untuk hidup sehat; (3) Meningkatkan koordinasi antara desa dengan bidan desa (sebagai fasilitator Desa Siaga Aktif) dan Puskesmas setempat dalam merencanakan dan melaksanakan upaya-upaya penanganan masalah kesehatan di desa. ${ }^{5}$

\section{Provinsi Kalimantan Barat}

Dalam Rencana Pembangunan Jangka Panjang Daerah (RPJMD) Provinsi Kalbar Tahun 2008-2028 dinyatakan bahwa visi pembangunan daerah adalah: "Kalimantan Barat Bersatu dan Maju". Dinyatakan bahwa kemajuan suatu daerah juga diukur berdasarkan indikator kependudukan. Terdapat kaitan yang erat antara kemajuan suatu daerah dengan laju pertumbuhan penduduk, termasuk derajat kesehatan. Daerah yang sudah maju ditandai dengan laju pertumbuhan penduduk yang lebih kecil, angka harapan hidup yang lebih tinggi, dan kualitas pelayanan sosial yang lebih baik. Secara keseluruhan kualitas Sumber Daya Manusia (SDM) yang makin baik akan tercermin dalam produktivitas yang makin tinggi.

Visi tersebut dijabarkan dalam 9 misi. Salah satu misi di antaranya adalah: "Mewujudkan masyarakat yang sehat, cerdas, produktif, dan inovatif", yaitu meningkatkan kualitas SDM melalui peningkatan tingkat pendidikan dan derajat kesehatan penduduk.
Hal itu tercermin pada tingkat pendidikan terendah, tingkat partisipasi anak usia sekolah, angka harapan hidup yang lebih tinggi, dan kualitas pelayanan sosial yang lebih baik. Dengan demikian berarti masyarakat diharapkan akan lebih produktif dan inovatif.

Selanjutnya dalam Bab IV Arah, Tahapan, dan Prioritas Pembangunan Jangka Panjang Tahun 2008-2028, dinyatakan bahwa salah satu sasaran pokok adalah "Terwujudnya Masyarakat yang Sehat, Cerdas, Produktif, Profesional, Mandiri, dan Inovatif", ditandai oleh meningkatnya kualitas SDM, termasuk peran perempuan dalam pembangunan.

Masyarakat yang sehat ditandai dengan menurunnya angka kematian anak (menjadi 2/3 dari kondisi tahun 1990) dan AKI (menjadi 3/4 dari kondisi tahun 1990) serta berkurangnya jumlah dan penyebaran HIV/AIDS, malaria, TBC dan penyakit lainnya. Masyarakat produktif, profesional, dan mandiri ditandai dengan semakin meningkatnya Tingkat Partisipasi Angkatan Kerja (TPAK), pengusaha, dan wiraswasta yang dapat menciptakan lapangan kerja, meningkatnya prestasi olahraga, dan meningkatnya Indeks Pembangunan Gender (IPG). Parameter-parameter tersebut merupakan sasaran pokok yang dirumuskan dalam MDGs.

Ada pun Arah Pembangunan Jangka Panjang Tahun 2008-2028 adalah "Mewujudkan Masyarakat yang Sehat, Cerdas, Produktif, Profesional, Mandiri dan Inovatif". Terciptanya kondisi masyarakat yang sehat, cerdas, produktif, profesional, mandiri dan inovatif sangat penting bagi terciptanya suasana kehidupan masyarakat yang penuh toleransi, tenggang rasa, dan harmonis. Mewujudkan masyarakat yang sehat, cerdas, produktif, profesional, mandiri dan inovatif berarti pula mewujudkan MDGs yang dirumuskan dalam 8 sasaran pokok.

Selanjutnya dalam Bab IV dinyatakan bahwa pembangunan SDM dilaksanakan dalam mewujudkan manusia Kalbar yang maju dan mandiri sehingga mampu berdaya saing dalam era globalisasi. Dalam kaitan itu, pembangunan SDM diarahkan pada peningkatan kualitas SDM Kalbar yang antara lain ditandai dengan meningkatnya Indeks Pembangunan Manusia (IPM) dan Indeks Pembangunan Gender (IPG), serta tercapainya penduduk tumbuh seimbang yang ditandai dengan angka reproduksi neto (Net Reproduction Ratel NRR) sama dengan 1, atau angka kelahiran total (Total Fertility Rate/TFR) sama dengan kurang dari 2,0 .

Pengendalian jumlah dan laju pertumbuhan penduduk diarahkan pada peningkatan pelayanan 
keluarga berencana dan kesehatan reproduksi yang terjangkau, bermutu, dan efektif menuju terbentuknya keluarga kecil yang berkualitas. Di samping itu, penataan persebaran dan mobilitas penduduk diarahkan menuju persebaran penduduk yang lebih seimbang sesuai dengan daya dukung dan daya tampung lingkungan melalui pemerataan pembangunan ekonomi dan wilayah dengan memerhatikan keragaman etnis dan budaya serta pembangunan berkelanjutan. Sistem administrasi kependudukan penting pula dilakukan untuk mendukung perencanaan dan pelaksanaan pembangunan di tingkat nasional dan daerah serta mendorong terakomodasinya hak penduduk dan perlindungan sosial.

Pembangunan pendidikan dan pelatihan serta pembangunan kesehatan merupakan investasi dalam meningkatkan kualitas SDM sehingga penting perannya dalam meningkatkan pertumbuhan ekonomi dan menurunkan tingkat kemiskinan dan pengangguran. Pembangunan kesehatan diarahkan untuk meningkatkan kesadaran, kemauan, dan kemampuan hidup sehat bagi setiap orang agar peningkatan derajat kesehatan masyarakat yang setinggi-tingginya dapat terwujud. Pembangunan kesehatan diselenggarakan dengan berdasarkan perikemanusiaan, pemberdayaan dan kemandirian, adil dan merata, serta pengutamaan dan manfaat dengan perhatian khusus pada penduduk rentan, antara lain ibu, bayi, anak, manusia usia lanjut, dan keluarga miskin. Pembangunan kesehatan dilaksanakan melalui peningkatan upaya kesehatan, pembiayaan kesehatan, SDM kesehatan, obat, dan perbekalan kesehatan yang disertai oleh peningkatan pengawasan, pemberdayaan masyarakat, dan manajemen kesehatan. Upaya tersebut dilakukan dengan memerhatikan dinamika kependudukan, epidemiologi penyakit, perubahan ekologi dan lingkungan, kemajuan ilmu pengetahuan dan teknologi, serta globalisasi dan demokratisasi dengan semangat kemitraan dan kerja sama lintas sektor. Penekanan diberikan pada peningkatan perilaku dan kemandirian masyarakat serta upaya promotif dan preventif. Pembangunan nasional harus berwawasan kesehatan, yaitu setiap kebijakan publik selalu memerhatikan dampaknya terhadap kesehatan.

Pembangunan pemberdayaan perempuan dan anak diarahkan pada peningkatan kualitas hidup dan peran perempuan, kesejahteraan, dan perlindungan anak di berbagai bidang pembangunan; penurunan jumlah tindak kekerasan, eksploitasi, dan diskriminasi terhadap perempuan dan anak; serta penguatan kelembagaan dan jaringan pengarusutamaan gender dan anak di tingkat nasional dan daerah, termasuk ketersediaan data dan statistik gender.

Salah satu SKPD yang memiliki kewenangan di bidang kesehatan reproduksi adalah SKPD yang menangani bidang pemberdayaan perempuan. Di Provinsi Kalbar tugas itu dilaksanakan oleh Badan Pemberdayaan Perempuan, Perlindungan Anak, dan Keluarga Berencana (BP3AKB). Tugas BP3AKB adalah mengoordinasikan dan memfasilitasi SKPD yang ada. BP3AKB mengambil kebijakan yang terkait dengan masalah perempuan dan anak. Jadi sifatnya koordinatif. BP3AKB mendukung atau mendorong agar SKPD fokus pada masalah perempuan dan anak, termasuk dalam masalah kesehatan reproduksi, antara lain Dinkes, Dinas Pendidikan, Dinas Sosial, dan BKKBN.

Untuk kesehatan reproduksi, fokusnya adalah anak, terutama remaja, karena hal ini sangat terkait dengan perlindungan anak yang merupakan tugas dan fungsi BP3AKB. Salah satu yang sedang dikerjakan saat ini adalah menyusun Rencana Aksi Daerah (RAD) tentang Pornografi. Sebelumnya sudah ada beberapa peraturan daerah (Perda) yang berkaitan dengan perlindungan perempuan dan anak, antara lain Peraturan Daerah No. 3 Tahun 2013 tentang Penyelenggaraan Kesehatan Reproduksi (Perda tentang Kesehatan Reproduksi.

Dalam Perda tentang Kesehatan Reproduksi, Pasal 4 ayat (1) menyatakan bahwa sasaran pengaturan dalam perda ini meliputi:

a. pengaturan kehamilan;

b. upaya kesehatan ibu, bayi dan anak;

c. kesehatan reproduksi remaja;

d. kesehatan usia lanjut; dan

e. kelompok kerja penyelenggaraan kesehatan reproduksi.

Ada pun ruang lingkup penyelenggaraan kesehatan reproduksi diatur dalam Pasal 4 ayat (2), meliputi:

a. konseling tentang seksualitas, kehamilan, alat kontrasepsi, aborsi, infertilitas, infeksi, dan penyakit;

b. pendidikan seksualitas:

c. pendidikan gender;

d. pencegahan, skrining, dan pengobatan infeksi saluran reproduksi, Infeksi Menular Seksual (IMS), termasuk HIV/AIDS dan masalah kebidanan lainnya;

e. pemberian informasi yang benar sehingga secara sukarela memilih alat kontrasepsi yang ada, dan pemberian pelayanan kontrasepsi bagi pasangan usia subur;

f. pencegahan dan pengobatan infertilitas; 
g. pelayanan aborsi yang aman berdasarkan pertimbangan medis, tata nilai dalam masyarakat dan agama;

h. Pelayanan kehamilan, persalinan oleh tenaga kesehatan, pelayanan pasca-kelahiran; dan

i. Pelayanan kesehatan untuk ibu, bayi, anak, remaja, dan usia lanjut.

Kewajiban pemerintah daerah antara lain diatur dalam Pasal 7, yaitu menjamin ketersediaan informasi, edukasi, konseling, dan memberikan dukungan penyediaan sarana pelayanan kesehatan reproduksi yang aman, bermutu, dan terjangkau masyarakat. Sedangkan tanggung jawab pemerintah daerah diatur dalam Pasal 9 ayat (1) yang menyatakan bahwa Pemerintah Provinsi bertanggung jawab terhadap penyelenggaraan upaya kesehatan masyarakat dengan prioritas pada upaya kesehatan ibu, bayi, dan anak. (2) Upaya kesehatan sebagaimana dimaksud pada ayat (1) tersebut bertujuan untuk menjaga kesehatan ibu sehingga mampu melahirkan generasi yang sehat dan berkualitas serta mengurangi AKI dan Angka Kematian Bayi (AKB). Upaya kesehatan sebagaimana dimaksud pada ayat (2) meliputi:

a. promotif, preventif, kuratif, dan/atau rehabilitatif pelayanan kesehatan;

b. mempermudah akses pelayanan kesehatan yang berkualitas kepada para ibu; dan

c. perlindungan melalui imunisasi secara cumacuma.

Berdasarkan wawancara dengan Kepala BKKN Provinsi Kalimantan Barat (Kalbar), sebelum Peraturan Pemerintah Nomor 61 Tahun 2014 tentang Kesehatan Reproduksi disahkan, Provinsi Kalbar telah memiliki peraturan daerah tentang kesehatan reproduksi, yaitu Peraturan Daerah Nomor 3 Tahun 2013 tentang Penyelenggaraan Kesehatan Reproduksi. Implementasi penyelenggaraan kesehatan reproduksi telah dilaksanakan, antara lain di Puskesmas. Ada pun kesehatan reproduksi yang terkait fungsi reproduksi menjadi tanggung jawab pemerintah daerah, terutama dinas terkait (Dinkes).

Dalam melaksanakan tugas dan fungsi yang terkait dengan penyelenggaraan kesehatan reproduksi, terdapat dua pendekatan atau jalur, yaitu jalur formal dan jalur informal. Jalur formal dilaksanakan bekerja sama dengan sekolah. Materi mengenai kesehatan reproduksi terintegrasi dengan beberapa mata pelajaran, tidak menjadi pelajaran tersendiri, dan melalui mata pelajaran ekstrakurikuler. Materi tersebut ada dalam pelajaran Ilmu Pengetahuan Alam serta Pendidikan Jasmani dan Kesehatan di tingkat SMP dan SMA.
Ada pun jalur informal dilaksanakan melalui komunitas. Kesehatan reproduksi terkait dengan fungsi rekreasi, fungsi prokreasi, dan organ reproduksi. Mengingat tingginya angka kelahiran remaja, maka mulai tahun 2014 kegiatan lebih difokuskan pendekatan kepada remaja melalui Genre (Gerakan Generasi Berencana). Hal itu dilakukan dengan membentuk Forum Genre di tingkat provinsi dan kabupaten/kota. Saat ini baru terbentuk di 2 kabupaten/kota, yaitu Kota Pontianak dan Kabupaten Kubu Raya. Ada pun di Kabupaten Kapuas Hulu baru terbentuk susunan organisasinya.

Isu yang dibahas dalam Genre ada 3, yaitu perilaku seks bebas, narkoba, dan HV/AIDS. Genre merupakan program nasional. Namun demikian khusus untuk Provinsi Kalbar terdapat slogan: Genre Kalbar Bisa (Bersatu, Inovatif, Sinergis, dan Adaptif). Slogan ini merupakan upaya untuk mentransfer permasalahan yang ada menjadi permasalahan lokal, terutama yang terkait dengan masalah pernikahan usia remaja. Saat ini kader Genre berjumlah 50 orang. Dinyatakan bahwa permasalahan yang ada secara nasional sering tidak dianggap sebagai permasalahan secara lokal. Perkawinan usia remaja pada awalnya tidak dianggap sebagai masalah di Provinsi Kalbar, padahal hal ini sangat terkait dengan kesehatan reproduksi. Kesadaran untuk mulai membentuk forum tersebut menunjukkan adanya kesadaran bahwa hal itu merupakan masalah. Selama ini tidak ada resistensi karena pendekatan dilakukan secara top down yaitu BKKBN melakukan pendekatan informal kepada seluruh lapisan masyarakat, terutama tokoh agama dan tokoh masyarakat. Ada pun dari pendekatan secara bottom up atau dari bawah dilakukan dengan menugaskan relawan untuk bergerak dari bawah, dari universitas, dan kelompok PIK. Hingga tahun 2014 BKKBN sudah melatih 200 relawan untuk menyebarkan informasi sampai ke kabupaten/kota.

Apabila melihat pada RPJMD Provinsi Jateng Tahun 2013-2018, dapat dikatakan bahwa kebijakan pembangunan di provinsi ini secara normatif telah berpihak kepada kesehatan reproduksi. Provinsi Jateng telah menyadari pentingnya masalah kesehatan reproduksi. Hal itu secara eksplisit dipaparkan dalam Bab II RPJMD. Dalam bab ini masalah kesehatan reproduksi dimasukkan menjadi salah satu aspek kesejahteraan masyarakat. Keputusan untuk menjadikan masalah kesehatan reproduksi sebagai aspek yang penting ini tampaknya dilatarbelakangi oleh kondisi di Provinsi Jateng yang menunjukkan adanya kecenderungan peningkatan AKI dalam kurun waktu 5 tahun (2008-2012), meskipun jika dibandingkan dengan 
angka nasional (SDKI Tahun 2012), angka ini masih berada di bawah angka nasional sebesar 359 per 100.000 penduduk.

Kebijakan Pemerintah Provinsi Jateng yang telah berperspektif gender tidak lepas dari kebijakan di bidang pemberdayaan perempuan dan perlindungan anak. Perspektif gender telah diintegrasikan ke dalam dokumen perencanaan mulai dari RPJMD, Renstra SKPD, dan Renja SKPD. Selain itu, beberapa isu gender juga telah terintegrasi di dalam beberapa Renstra SKPD, antara lain pada Renstra Dinas Tenaga Kerja, Transmigrasi dan Kependudukan; Dinas Pendidikan; serta Dinas Peternakan dan Kesehatan Hewan.

Kondisi yang agak berbeda ditemukan di Provinsi Kalbar. Jauh sebelum Peraturan Pemerintah Nomor 61 Tahun 2014 tentang Kesehatan Reproduksi diterbitkan, provinsi ini telah memiliki Perda tentang Penyelenggaraan Kesehatan Reproduksi. Apabila melihat isi Perda tersebut, maka peraturan ini telah mengatur berbagai aspek dalam kesehatan reproduksi, antara lain pengaturan kehamilan; upaya kesehatan ibu, bayi dan anak; dan kesehatan reproduksi remaja. Bahkan Perda ini juga telah mengatur kesehatan usia lanjut; dan kelompok kerja penyelenggaraan kesehatan reproduksi.

Selain memiliki Perda tentang Penyelenggaraan Kesehatan Reproduksi, kantor wilayah BKKBN di provinsi ini juga aktif mengkampanyekan slogan Genre Kalbar Bisa (Bersatu, Inovatif, Sinergis, dan Adaptif) dan membentuk Forum Genre di tingkat provinsi dan kabupaten/kota. Sementara ini Forum Genre memang baru terbentuk di dua wilayah, yaitu Kota Pontianak dan Kabupaten Kubu Raya. Namun hingga saat ini BKKBN terus mendorong agar seluruh kabupaten memiliki Forum Genre.

\section{Hambatan dalam Penyelenggaraan Kesehatan Reproduksi \\ Provinsi Jawa Tengah}

Dalam wawancara dengan narasumber dari Dinkes, disampaikan bahwa sampai saat ini masih ditemukan permasalahan dalam pelaksanaan pelayanan kesehatan bagi ibu dan anak, antara lain belum terpenuhinya sarana dan prasarana pelayanan kesehatan dan belum meratanya pendayagunaan dan kompetensi tenaga kesehatan.

Terkait dengan ketersediaan sarana dan prasarana pelayanan kesehatan, jika dibandingkan dengan jumlah penduduk masih belum proporsional, sehingga masih diperlukan optimalisasi pelayanan kesehatan di tingkat dasar dan rujukan yang sesuai dengan standar pelayanan kesehatan.

Khusus terkait dengan penyelenggaraan kesehatan reproduksi perempuan, masalah utama yang dihadapi oleh Provinsi Jateng adalah tingginya AKI. Hal ini ditegaskan dalam dokumen perencanaan pembangunan provinsi ini. Dalam RPJMD, Bab IV Analisis Isu-Isu Strategis, kesehatan merupakan salah satu permasalahan pembangunan daerah. Permasalahan terkait dengan pembangunan kesehatan di Provinsi Jateng adalah tingginya AKI dari 114,42 per 100.000 kelahiran hidup (tahun 2008) menjadi 116,34 per 100.000 kelahiran hidup (tahun 2012). Pada saat dilakukan wawancara dengan narasumber dari Dinkes Provinsi Jateng, disampaikan bahwa AKI per triwulan I tahun 2015 (10 Juni 2015) hanya turun sedikit, menjadi 115 per 100.000 kelahiran hidup. Masih tingginya AKI ini menurut narasumber disebabkan oleh beberapa faktor, yaitu:

1. meningkatnya jumlah kehamilan risiko tinggi;

2. masih rendahnya deteksi dini masyarakat; dan

3. kurangnya kecepatan dan ketepatan pengambilan keputusan rujukan pada kehamilan risiko tinggi.

Selain itu, dari wawancara dengan narasumber di Dinkes juga diperoleh informasi tentang masih adanya kendala dalam penyelenggaraan kesehatan reproduksi perempuan, antara lain:

1. belum meratanya tingkat pendidikan, terutama di daerah pedesaaan;

2. masih adanya budaya masyarakat yang menghambat penyelenggaraan kesehatan reproduksi perempuan, misalnya lebih memilih dukun untuk membantu persalinan;

3. masih belum maksimalnya keterlibatan aparat. Sebagai catatan, Provinsi Jateng terdiri dari 35 kabupaten/kota, dan di setiap kabupaten/kota tingkat keterlibatan aparat sangat bervariasi.

\section{Provinsi Kalimantan Barat}

Dalam wawancara dengan narasumber dari BP3AKB, dinyatakan bahwa salah satu masalah yang dihadapi oleh Provinsi Kalbar adalah masalah pernikahan dini. Selama ini dalam masyarakat terdapat pola asuh yang salah dalam keluarga yang menganggap bahwa pernikahan dini adalah sebuah hal yang wajar. Hal ini merupakan dampak dari kemajuan teknologi. Masyarakat belum siap secara mental dan psikologis dalam menghadapi kemajuan teknologi yang sangat cepat, termasuk dalam masalah pornografi (mudah diakses), sehingga terjadi kesenjangan di antara keduanya. Pornografi dianggap sebagai hal biasa. Sudah terjadi pergeseran sosial dalam masyarakat. Hal ini menjadi dilema di kalangan keluarga di Provinsi Kalbar karena 80 persen kehamilan pada anak dan remaja merupakan kehamilan yang tidak diinginkan (KTD). Hal ini akan berdampak pada perlindungan anak, karena 
hak anak menjadi tidak terlindungi dan terpenuhi. Karena menikah pada usia muda, maka potensi untuk terjadinya perceraian juga tinggi. Hal ini juga akan berdampak pada munculnya permasalahan hukum, terutama terkait hak asuh atas anak yang dilahirkan.

Dengan demikian masalah pornografi terkait erat dengan masalah pernikahan dini yang menjadi fenomena di Provinsi Kalbar. RAD tentang Pornografi diharapkan dapat digunakan sebagai upaya untuk mencegah dampak pornografi sekaligus melindungi anak dari bahaya pronografi. Penyusunan RAD melibatkan seluruh SKPD yang terkait, dengan Bappeda sebagai leading sector. BP3AKB hanya memfasilitasi dan mengoordinasikan kegiatan penyusunan RAD. Draft awal RAD sudah ada. Saat ini penyusunan RAD baru sampai pada tahap penyusunan jadwal kegiatan dan Bab I (Pendahuluan) sudah selesai disusun. Rencananya akan dibentuk Gugus Tugas Pornografi.

Untuk masalah pernikahan dini, BP3AKB bekerja sama dengan Kanwil Kemenag, terutama terkait data tentang jumlah pernikahan dan perceraian. BP3AKB akan mengundang SKPD terkait, termasuk Kemenag serta Kementerian Hukum dan HAM untuk mensosialisasikan rencana penyusunan RAD. Penyusunan RAD juga melibatkan akademisi dari Universitas Tanjungpura dan Politeknik Kesehatan serta LSM.

Sedangkan menurut Kepala BKKBN Provinsi Kalbar, persoalan kesehatan reproduksi yang menonjol di Provinsi Kalbar adalah tingginya angka melahirkan pada usia remaja (15-19 tahun), yang merupakan angka tertinggi se-Indonesia. Hasil SDKI tahun 2012 menunjukkan, angka melahirkan pada usia remaja sebesar 104 per 1.000 penduduk.

Ada pun hambatan yang dihadapi dalam penyelenggaraan kesehatan reproduksi di provinsi ini menurut narasumber dari $\mathrm{BP} 3 \mathrm{AKB}$ yaitu:

1. Budaya;

2. Kesiapan masyarakat, tingkat pendidikan yang rendah, dan tingkat angka putus sekolah yang tinggi;

3. Kondisi geografis. Wilayah Kalbar yang luas, sementara kegiatan lapangan terbatas;

4. SDM terbatas, analisis beban kerja belum jelas; dan

5. SDM banyak mengerjakan di luar tugas dan fungisinya, misalnya mewakili pimpinan dalam acara tertentu.

Sebagaimana telah disampaikan pada bagian sebelumnya, masalah yang berkaitan dengan kehamilan dan persalinan, termasuk AKI tidak dapat dilepaskan dari berbagai faktor yang memengaruhinya, antara lain derajat kesehatan ibu dan kesiapan untuk hamil, pemeriksaan antenatal (masa kehamilan), pertolongan persalinan dan perawatan segera setelah persalinan, serta faktor sosial budaya (Poerwandari dan Akmal, 2000: 436). Di Provinsi Jateng masih belum proporsionalnya perbandingan antara jumlah penduduk yang membutuhkan dengan ketersediaan sarana dan prasarana pelayanan kesehatan membuat penyelenggaraan pelayanan kesehatan kepada masyarakat belum optimal, termasuk di dalamnya pelayanan kesehatan reproduksi, terutama untuk pertolongan persalinan.

Selain itu, terbatasnya akses perempuan terhadap fasilitas pelayanan kesehatan reproduksi yang berkualitas, sebagai salah satu tantangan yang dihadapi dalam pencapaian MDGs 5 Target $5 \mathrm{~A}$ juga menjadi permasalahan yang dihadapi oleh Pemerintah Provinsi Jateng. Keterbatasan akses ini juga sesuai dengan analisis WHO yang menunjukkan bahwa akses dan kontrol terhadap sumber daya, dalam hal ini terhadap ketersediaan dan kualitas layanan menjadi salah satu faktor yang berdampak terhadap status kesehatan perempuan.

Berbagai hambatan dan keterbatasan tersebut telah dicoba untuk diatasi oleh Pemerintah Provinsi Jateng, dalam hal ini Dinkes melalui berbagai program, antara lain Pogram Desa Siaga Aktif yang mencakup upaya promotif, preventif, dan kuratif yang dilaksanakan oleh tenaga kesehatan (bidan) dan melibatkan kader atau tenaga sukarela. Program lainnya adalah Program Rumah Tinggal Kelahiran, yang sudah dilaksanakan di beberapa kabupaten/kota, antara lain Banjarnegara, Cilacap, dan Tegal serta Rumah Singgah untuk ibu hamil yang telah diinisiasi di 5 kabupaten, yaitu: Cilacap, Temanggung, Wonosobo, Banjarnegara, dan Jepara.

Mengingat Provinsi Jateng meliputi wilayah yang luas, mencakup 35 kabupaten/kota, maka upaya yang dilakukan untuk meningkatkan pelayanan kesehatan reproduksi dan menurunkan AKI sudah tepat karena difokuskan pada wilayahwilayah yang memiliki kasus kematian ibu yang tinggi seperti Kabupaten Brebes, Tegal, Pemalang, Cilacap, Grobogan, Banyumas, Pekalongan, dan Batang.

Ada pun berbagai upaya di bidang kesehatan reproduksi yang dilaksanakan di Provinsi Kalbar tampaknya ada hubungannya dengan masalah utama yang dihadapi oleh Provinsi Kalbar di bidang kependudukan, yaitu kecenderungan pernikahan dini dan tingginya angka melahirkan pada remaja. Sebagaimana dinyatakan oleh narasumber dari BKKBN Provinsi Kalbar, berdasarkan hasil SDKI tahun 2012, angka melahirkan pada usia 
remaja di Provinsi Kalbar masih sebesar 104 per 1.000 penduduk. Angka ini merupakan angka yang tertinggi dibandingkan provinsi lainnya di Indonesia. Oleh karena itu, upaya yang dilakukan untuk mengatasi hambatan dalam penyelenggaraan reproduksi di Provinsi Kalbar juga difokuskan pada program dan kegiatan yang dapat mengurangi angka pernikahan dini dan tingginya angka kelahiran pada remaja sebagaimana dilaksanakan oleh BKKBN Provinsi Kalbar.

\section{Penutup \\ Simpulan}

Berdasarkan uraian pada bagian sebelumnya, dapat disimpulkan beberapa hal berikut: pertama, kebijakan pemerintah daerah terkait dengan penyelenggaraan kesehatan reproduksi di dua daerah yang diteliti cukup baik. Di Provinsi Jateng, tingginya AKI telah menjadi salah satu fokus dalam RPJMD Tahun 2013-2018. Salah satu upaya yang dilakukan untuk menekan AKI adalah dengan melaksanakan Program Desa Siaga Aktif, sebuah pelayanan dasar bagi masyarakat desa yang meliputi upaya promotif, preventif, dan kuratif yang dilaksanakan oleh tenaga kesehatan (bidan) dan melibatkan kader atau tenaga sukarela lainnya. Program lainnya untuk menurunkan AKI antara lain Program Rumah Tinggal Kelahiran, yang sudah dilaksanakan di beberapa kabupaten/kota, antara lain Banjarnegara, Cilacap, dan Tegal serta Rumah Singgah untuk ibu hamil yang telah diinisiasi di 5 kabupaten, yaitu: Cilacap, Temanggung, Wonosobo, Banjarnegara, dan Jepara.

Ada pun di Provinsi Kalbar, sebelum Peraturan Pemerintah Nomor 61 Tahun 2014 tentang Kesehatan Reproduksi diterbitkan, telah terdapat Peraturan Daerah No. 3 Tahun 2013 tentang Penyelenggaraan Kesehatan Reproduksi. Perda tersebut mengatur bahwa penyelenggaraan kesehatan reproduksi meliputi: (1) pengaturan kehamilan; (2) upaya kesehatan ibu, bayi dan anak; (3) kesehatan reproduksi remaja; (4) kesehatan usia lanjut; dan (5) kelompok kerja penyelenggaraan kesehatan reproduksi. Selain itu, mengingat salah satu permasalahan menonjol dalam kesehatan reproduksi di Provinsi Kalbar adalah pernikahan usia remaja, BKKBN bekerja sama dengan SKPD terkait mengkampanyekan slogan Genre Kalbar Bisa (Bersatu, Inovatif, Sinergis, dan Adaptif) dan membentuk Forum Genre di tingkat provinsi dan kabupaten/kota, yaitu Kota Pontianak dan Kabupaten Kubu Raya.

Terkait dengan implementasi Peraturan Pemerintah Nomor 61 Tahun 2014 tentang Kesehatan Reproduksi di daerah, kedua provinsi telah melaksanakan beberapa hal yang diatur dalam PP tersebut, terutama yang terkait dengan penyelenggaraan kesehatan reproduksi remaja dan upaya penurunan AKI. Ada pun menyangkut masalah aborsi yang terdapat dalam PP tersebut, kedua daerah tidak terlalu memerhatikan masalah tersebut dan selama ini tidak menganggapnya sebagai masalah.

Kedua, hambatan dalam penyelenggaraan kesehatan reproduksi. Di Provinsi Jateng pelaksanaan pelayanan kesehatan bagi ibu dan anak masih terhambat oleh belum terpenuhinya prasarana dan sarana serta meratanya pendayagunaan dan kompetensi tenaga kesehatan. Sarana pelayanan kesehatan masih belum proporsional jika dibandingkan dengan jumlah penduduk, sehingga masih diperlukan optimalisasi pelayanan kesehatan di tingkat dasar dan rujukan yang sesuai dengan standar pelayanan kesehatan. Demikian pula dengan Provinsi Kalbar. Selain pelayanan kesehatan belum optimal, tingginya angka pernikahan dini menjadi salah satu masalah yang dihadapi dalam penyelenggaraan kesehatan reproduksi.

\section{Saran}

Meskipun kedua provinsi telah mengimplementasikan kebijakan yang terkait dengan penyelenggaraan kesehatan reproduksi perempuan, terdapat beberapa upaya yang dapat dilakukan untuk meningkatkan kualitas pelayanan kesehatan reproduksi perempuan, termasuk upaya untuk menurunkan AKI. Program Desa Siaga Aktif dan Program Rumah Tinggal Kelahiran yang telah dilaksanakan oleh Provinsi Jateng perlu terus dijalankan dan ditingkatkan kualitasnya, antara lain dengan melakukan monitoring dan evaluasi, sehingga efektivitas program-program tersebut dapat diketahui dan berbagai hambatan dalam implementasi kedua program dapat semakin diminimalisasi. Untuk Provinsi Kalbar, program dan kegiatan yang selama ini masih fokus pada upaya untuk menurunkan angka pernikahan dini perlu dilengkapi dengan program dan kegiatan yang ditujukan kepada ibu hamil dan melahirkan, sehingga dapat mendukung upaya untuk menurunkan AKI. Untuk mengatasi hambatan dalam penyelenggaraan kesehatan reproduksi perempuan, Provinsi Jateng perlu terus meningkatkan upaya untuk menambah prasarana dan sarana pelayanan kesehatan agar makin proporsional dengan jumlah penduduk, pemerataan pendayagunaan dan kompetensi tenaga kesehatan, serta optimalisasi pelayanan kesehatan di tingkat dasar dan rujukan yang sesuai dengan standar pelayanan kesehatan. Upaya untuk meningkatkan kualitas pelayanan kesehatan di Provinsi Kalbar juga perlu terus dilakukan. Selain itu, cakupan program BKKBN Provinsi Kalbar melalui kampanye "Genre Kalbar Bisa" perlu diperluas dan perlunya 
pembentukan Forum Genre di seluruh wilayah kabupaten yang ada di Provinsi Kalbar, sehingga dapat lebih efektif dalam menekan atau mengurangi angka pernikahan dini.

\section{DAFTAR PUSTAKA}

\section{Buku}

Badan Penelitian dan Pengembangan Kesehatan Kementerian Kesehatan. 2010. Riset Kesehatan Dasar (Riskesdas) 2010.

Departemen Kesehatan. 1998. Upaya Akselerasi Penurunan Angka Kematian Ibu.

Kementerian Perencanaan Pembangunan Nasional/ Badan Perencanaan Pembangunan Nasional. 2010. Laporan Pencapaian Tujuan Pembangunan Milenium di Indonesia 2010.

Lubis, Firman, 2000. "Ibu Omas dan Gerakan Kesehatan Reproduksi di Tanah Air," dalam Benih Bertumbuh, Kumpulan Karangan untuk Prof. Tapi Omas Ihromi, Sita van Bemmelen, Atashendartini Habsjah, Lugina Setyawati (ed). Yogyakarta: Yayasan Galang.

Mosse, Julia Cleves. 2007. Gender dan Pembangunan. Rifka Annisa Women's Crisis Centre dan Cetakan V. Yogyakarta: Pustaka Pelajar.

Muhammad, Kartono. 1996. Prioritas Pelayanan Kesehatan Reproduksi dalam Seksualitas Kesehatan Reproduksi dan Ketimpangan Gender. Yogyakarta: Pustaka Sinar Harapan.

Mundayat, Aris Arif, dkk. 2010. Target MDGs Menurunkan Angka Kematian Ibu Tahun 2015 Sulit Dicapai. Jakarta: Women Research Institute.

Poerwandari, E. Kristi, Yenina Akmal. 2000. Kondisi Sosial-Budaya Suku Sentani dan Implikasinya pada Kesehatan Reproduksi Perempuan, dalam Perempuan Indonesia dalam Masyarakat yang Tengah Berubah, 10 Tahun Program Kajian Wanita, E. Kristi Poerwandari dan Rahayu Surtiati Hidayat (ed). Jakarta: Program Studi Kajian Wanita Program Pascasarjana Universitas Indonesia.

Rahman, Anita. 2006. "Hukum dan Hak Kesehatan Reproduksi Perempuan: Masalah Aborsi," dalam Perempuan dan Hukum: Menuju Hukum yang BerperspektifKesetaraan dan Keadilan, Sulistyowati Irianto (ed). Jakarta: Yayasan Obor Indonesia.

\section{Jurnal}

Azinar, Muhammad. 2013. "Perilaku Seksual Pranikah Berisiko terhadap Kehamilan Tidak Diinginkan." Jurnal Kesehatan Masyarakat, Vol. 8, No.2.
Darwin, Muhadjir. 1996. "Kesehatan Reproduksi: Ruang Lingkup dan Kompleksitas Masalah." Jurnal Populasi, Vol. 7 No. 2. Yogyakarta: Pusat Studi Kependudukan dan Kebijakan, Universitas Gadjah Mada.

DeLamater, John dan Sara M. Moorman. 2007. Sexual Behavior in Later Life. Journal of Aging and Health, 20 (10). Habsjah, Atashendartini. 2008. "Kesehatan Perempuan: Perspektif Feminis." Jurnal Perempuan. No.61: Pendidikan, Media dan Gender. Jakarta: Yayasan Jurnal Perempuan, Desember.

Jekti, Rabea Pangerti dan Mutiatikum, D. 2011. "Hubungan antara Kepatuhan Antenatal Care dengan Pemilihan Penolong Persalinan." Jurnal Kesehatan Reproduksi Vol. 1 No. 2, April.

Suryawati, Chriswardani. 2007. "Faktor Sosial Budaya dalam Praktik Perawatan Kehamilan, Persalinan, dan Pasca Persalinan (Studi di Kecamatan Bangsri Kabupaten Jepara).“ Jurnal Promosi Kesehatan Indonesia Vol. 2 No. 1, Januari.

Suryoputro, Antono. 2006. "Faktor-faktor yang Mempengaruhi Perilaku Seksual Remaja di Jawa Tengah: Implikasinya terhadap Kebijakan dan Layanan Kesehatan Seksual dan Reproduksi.“ Jurnal Makara, Vol. 10 No. 1.

Wahyuni, Budi. 1997. "Alat Kontrasepsi dan Kesehatan Reproduksi." Jurnal Perempuan No.04: Rahim Ini Milik Siapa?. Jakarta: Yayasan Jurnal Perempuan, Agustus - Oktober 1997.

\section{Dokumen}

Undang-Undang Nomor 7 Tahun 1984 tentang Pengesahan Konvensi mengenai Penghapusan Segala Bentuk Diskriminasi terhadap Wanita.

Undang-Undang Nomor 36 Tahun 2009 tentang Kesehatan.

Peraturan Pemerintah Nomor 61 Tahun 2014 tentang Kesehatan Reproduksi.

\section{Surat kabar}

"Hari Ibu, Momentum Percepatan Pencapaian MDGs 2015”, Suara Pembaruan, 27 Desember 2009.

"Infrastruktur Kesehatan Ditata", Media Indonesia, 9 Januari 2015.

"Jumlah Bidan Desa Minim", Media Indonesia, 8 Juli 2011.

"Membangun Sistem non-Diskriminatif", Swara, Kompas, 25 Juni 2011.

"Pembangunan Milenium: Desentralisasi Hambat Pencapaian Target", Kompas, 14 Maret 2015.

“Transformasi Tiada Henti”, Kompas, 20 April 2012. 


\section{Intenet}

"Human Development Report 2015 Work for Human Development Briefing Note for Countries on the 2015 Human Development Report Indonesia," http:/hdr.undp.org/sites/all/themes/hdr_theme/ country-notes/IDN.pdf, diakses 7 Maret 2016.

"Pengembangan Desa Siaga Aktif," http://www. dinkesjatengprov.go.id/2015/index.php/39rokcontent/frontpage/111-pengembangan-desasiaga-aktif, diakses 18 Juni 2015.
Republika Rabu, 16 Desember 2015. “Angka Kematian Ibu di Indonesia Masih Tinggi," http://nasional. republika.co.id/berita/nasional/umum/15/12/16/ nzghga383-angka-kematian-ibu-di-indonesiamasih-tinggi), diakses tanggal 7 Januari 2016.

"SDGs Gantikan MDGs sebagai Acuan Perundingan Pembangunan," http://www.antaranews.com/ berita/453769/sdgs-gantikan-mdgs-sebagai-acuanperundingan-pembangunanSDGs, diakses 5 Maret 2015. 